\title{
TITLE:
}

\section{FIVE NEW MINUTE BIVALVES FROM JAPAN (ERYCINACEA, PELECYPODA)}

$\operatorname{AUTHOR}(\mathrm{S})$ :

Habe, Tadashige

\section{CITATION:}

Habe, Tadashige. FIVE NEW MINUTE BIVALVES FROM JAPAN (ERYCINACEA, PELECYPODA). PUBLICATIONS OF THE SETO MARINE BIOLOGICAL LABORATORY 1959, 7(2): 291-294

ISSUE DATE:

1959-05-30

URL:

http://hdl.handle.net/2433/174603

RIGHT: 


\title{
FIVE NEW MINUTE BIVALVES FROM JAPAN \\ (ERYCINACEA, PELECYPODA $)^{1,2)}$
}

\author{
TADASHIGE HABE \\ Amakusa Marine Biological Laboratory \\ (Kyushu University)
}

With 15 Text-figures

The minute molluscs are still inadequately known in Japan. Therefore there are many undetermined species before the writer. These five new bivalves here described are widely found in the bays of Japan, but have never been named elsewhere.

\section{Family Erycinidae}

Kellia tsujitai sp. nov.

(Text-figs. 1, 2)

Shell is small, but rather thick, light yellowish white, tumid, suborbicular, slightly longer than high. Ventral margin is rather straight. Surface is dull, with the roughened growth lines and two obtuse angles run to the antero-ventral and posteroventral corners from the prominent umbo. In the left valve a projecting conical cardinal tooth is just under the umbo and a small anterior cardinal on the hinge plate and the posteior lateral tooth is narrow but distinct. In the right valve a conical cardinal tooth and a narrow slot for the reception of the corresponding tooth on the left valve. A large brown resilium between the cardinal teeth and posterior lateral tooth on the left valve.

Length $4.7 \mathrm{~mm}$, height $4.1 \mathrm{~mm}$ and breadth $1.5 \mathrm{~mm}$. (left valve) (type specimen)

Length $4.6 \mathrm{~mm}$, height $3.7 \mathrm{~mm}$ and breadth $1.2 \mathrm{~mm}$. (left valve)

Type locality: Ariake Sea, Kyushu.

Distribution: Hakata Bay, Fukuoka Pref. and Amakusa, Kumamoto Pref., Kyushu ; Tanabe Bay, Wakayama Pref., Honshu.

1) Contributions from the Amakusa Marine Biological Laboratory (Kyushu University), No. 128.

2) Contributions from the Seto Marine Biological Laboratory, No. 328.

Publ. Seto Mar. Biol. Lab., VII (2), 1959. (Article 16) 
Remarks: This species very closely relates to $K$. japonica PILSBRy which may be a synonym of $K$. subrotunda DunKer and $K$. porculus PILSBRy, but is quite smaller and thicker even in the adult, with the roughened dull surface.

The writer takes pleasure in naming this new species in honor of Dr. Tokimi Tsurrta of the Seikai Regional Fisheries Laboratory in Nagasaki.

\section{Genus Borniopsis nov.}

Type species: Borniopsis tsurumaru sp. nov.

Shell is small, ovate, rather thick, light yellowish white to light purplish white, flat to moderately inflated. The postero-dorsal margin is shorter than the postero-dorsal owing to the greatly produced anterior part. Therefore the small umbo places one third from the posterior end. Surface with the fine radial threads all over. The left valve with two divaricating cardinal teeth, the anterior one being stronger and between them an internal ligament fixes, but right valve with one small tooth between the anterior and posterior cardinals.

Remarks: This new genus closely resembles the genera Borniola IREDALE and Byssobornia IREDALE in the surface sculpture, but has a thicker shell which is ovate in shape. The hinge armature is also differentiated this new genus from other two genera in having the narrow hinge plate with a weak lateral groove on the right valve.

Recently three species belonging to this new genus were found : namely Montacuta yamakawai Yoкоу AMA (=Mysella yamakawai by Is. TAKI and Oy AMA), Borniopsis tsurumaru sp. nov. and Borniopsis ariakensis sp. nov. The first species was described for so young specimens that it was only known imperfectly.

\section{Borniopsis tsurumaru sp. nov.}

(Text-figs. 10-12)

Shell is rather thick, light yellowish white, ovate, strongly produced anteriorly. Therefore the umbo places hinder than the middle of the dorsal margin. Surface with weak growth lines, but some of them are distict and distantly places as resting stages. Fine radiating threads run all over the surface.

Length $10.7 \mathrm{~mm}$, height $7.4 \mathrm{~mm}$ and breadth $2.1 \mathrm{~mm}$. (left valve) (type specimen)

Length $10.7 \mathrm{~mm}$, height $7.5 \mathrm{~mm}$ and breadth $2.2 \mathrm{~mm}$. (right valve)

Type locality: Ariake Sea, Kyushu.

Distribution: Tanabe Bay, Wakayama Pref., Ago Bay, Mie Pref., Mikawa Bay, Aichi Pref., Maizuru Bay, Kyoto Pref. and Nanao Bay, Ishikawa Pref., all of Honshu.

Remarks: The 'Tsurumaru' is a ship of the Fisheries Experiment Station of Nagasaki Prefecture, by which the first fisheries survey of Ariake Sea was carried out in 1957 and the writer obtained this new species from the inner part of this bay. 


\section{Borniopsis ariakensis sp. nov.}

(Text-figs. 13-15)

Shell is rather flat, light purplish white, rather thick, elongated ovate. The frontal part from the umbo is longer than the hinder. Surface with very fine radial threads and also fine growth lines all over. The latter is sometimes strong indicating the resting periods.

Length $12.3 \mathrm{~mm}$, height $7.9 \mathrm{~mm}$ and breadth $2.4 \mathrm{~mm}$. (right value) (type specimen)

Length $9.2 \mathrm{~mm}$, height $4.2 \mathrm{~mm}$ and breadth $1.6 \mathrm{~mm}$. (left valve)

Type locality: Ariake Sea, Kyushu.

Distribution: Maizuru Bay, Kyoto Pref., Honshu.

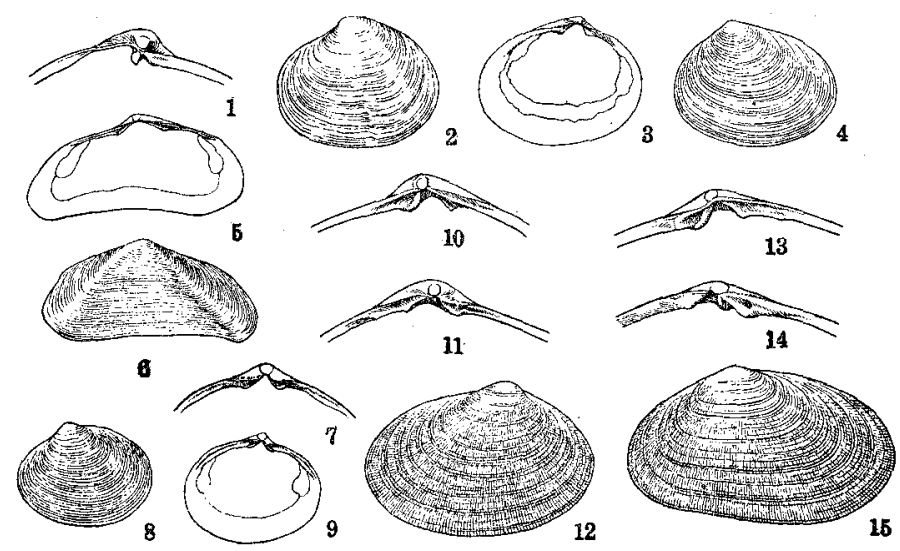

Text-figs. 1, 2. Kellia tsujitai sp. nov., 3, 4. Montacutona tanakai sp. nov., 5, 6. Curvemysella paula (A. AdAMS), 7-9. Montacutona olivacea sp. nov., 10-12. Borniopsis tsurumaru gen. et sp. nov., 13-15. Borniopsis ariakensis $\mathrm{sp}$. nov.

\section{Family Montacutidae}

\section{Montacutona tanakai sp. nov.}

(Text-figs. 3, 4)

Shell is small, flat. and orbicular in shape. Umbo is a little anterior from the middle of the dorsal margin. Surface is smooth and polished and marked weak growth lines only. In the left valve, the resilium between the two cardinal teeth which are rather strong and divaricate widely. In the right valve the dorsal margin fixes into groove between the dorsal margin and the solid cardinal teeth of the opposite valve.

Length $4.6 \mathrm{~mm}$, height $4.0 \mathrm{~mm}$ and breadth $1.0 \mathrm{~mm}$. (left valve) (type specimen)

Type locality: Ariake Sea, Kyushu. 
Distribution: Tanabe Bay, Wakayama Pref., Ago Bay, Mie Pref., Maizuru Bay, Kyoto Pref., all of Honshu.

Remarks: This new species is close to M.mutsuwanensis Yamamoto and НaBE, but has a distinctly oblique umbo to anterior direction. Montacutona japonica (YoKoyAma) is also an allied form to this new species, but has a more oblique shell with more solid cardinal teeth. This species was collected from Tanabe Bay and Miho Bay, Tottori Pref., Honshu.

The specific name is dedicated to Mr. Yataro Tanaka of the Hama Branch of the Seikai Regional Fisheries Laboratory who collected this new species from this Bay.

\section{Montacutona olivacea sp. nov.}

(Text-figs. 7-9)

This new species is quite similar to the preceding species in shape, but has a thin shell colored in olive. The left valve has the widely divaricated cardinal teeth and the shallow grooves along both the anterior and posterior dorsal margins.

Length $6.0 \mathrm{~mm}$, height $4.6 \mathrm{~mm}$ and breadth $1.1 \mathrm{~mm}$. (left valve) (type specimen)

Type locality: Maizuru Bay, Kyoto Pref., Honshu.

Distribution: Tanabe Bay, Wakayama Pref., Ago Bay, Mie Pref. and Miho Bay, Tottori Pref., all of Honshu.

\section{Genus Curvemysella nov.}

Type species: Mysella paula A. Adams (Text-figs. 5, 6).

Mysella paula A. AdAms is not a real member of the genus Mysella Angas in having the hinge armature of Montacuta-type and has the close relationships to the genus Montacuta rather than the genus Mysella. The shell curves owing to the symbiotic life with the hermit crab and the anterior cardinal tooth is elongate along the anterior dorsal margin. This peculiar features give a new genus Curvemysella for this species.

\section{REFERENCES}

Dali, W. H., P. BArtsch and H. A. Rehder 1938. Bernice P. Bishop Mus., Bull., 153, $135-149$. LAseron, Ch. F. 1956. Rec. Austr. Mus., 24 (2), 7-21.

TAKI, Is. and K. OYAMA 1954. Paleont. Soc. Japan, Sp. Paper 2, 41.

Yamamoto, G. and T. Habe 1959. Bull. Mar. Biol. Stat. Asamushi, 9 (3), 91-93.

Yokoyama, M. 1922. Jour. Coll. Sci. Imp. Univ. Tokyo, 44 (1), 157-158. 